\section{РАХУНКИ БУХГАЛТЕРСЬКОГО ОБЛІКУ: МИНУЛЕ ТА СЬОГОАЕННЯ ${ }^{\odot}$}

Л.В. КОВАЛЬ, кандидат економічних наук, доцент кафедри бухгалтерського обліку, Вінницький національний аграрний університет (м. Вінниця)

У статті розкрито історичні аспекти формування обліку як науки. Досліджено періодизацію розвитку бухгалтерського обліку за етапами. Розкрито формування облікової думки у різних краӥнах світу. Здійснено узагальнену класифікацію рахунків бухгалтерського обліку, спираючись на їхній історичний розвиток.

Досліджено передумови виникнення подвійного запису та порядок його застосування. Визначено період виникнення терміну «бухгалтер» та, як наслідок, професії «бухгалтер». Досліджено складові процесу розвитку облікової науки за Л. Пачолі. Виокремлено напрямки розвитку обліку за обліковою літературою у період до $20 \mathrm{~cm}$.

У результаті дослідження сформовано висновки та пропозииії.

Ключові слова: облік, рахунки, облікові школи, розвиток обліку, рахівництво, подвійний запис.

Табл.: 4. Літ.: 13.

\title{
ACCOUNTING RECORDS: PAST AND PRESENT
}

\author{
KOVAL Lubov, \\ Candidate of Economic Sciences, \\ Associate Professor of the Accounting Department, \\ Vinnytsia National Agrarian University
}

(Vinnytsia)

The article considers the historical aspects of the formation of accounting as a science. The periodization of the development of accounting by stages is investigated. The formation of accounting thought in different countries of the world is revealed. A generalized classification of accounting records is made, which is based on their historical development.

The prerequisites of the occurrence of a double entry and the order of its application are investigated. The period of occurrence of the term "accountant" and, as a consequence, the profession "accountant" is determined. The components of the process of development of accounting science by L. Pacholi are investigated. The directions of accounting development on the base of accounting literature in the period up to the 20th century are singled out.

As a result of the study, conclusions and suggestions were formulated.

(ㄷ) Л.В. КОВАЛЬ, 2019 
Key words: bookkeeping, accounts, accounting schools, accounting development, accounting, double entry.

Tabl.: 4. Lit.: 13.

\title{
СЧЕТА БУХГАЛТЕРСКОГО УЧЁТА: ПРОШЛОЕ И НАСТОЯЩЕЕ
}

\author{
КОВАЛЬ Любовь Витальевна, \\ кандидат экономических наук, доцент \\ кафедры бухгалтерского учёта, \\ Винницкий национальный аграрный университет \\ (2. Винница)
}

В статье раскрыты исторические аспекты формирования учёта как науки. Исследована периодизачию развития бухгалтерского учёта по этапам. Раскрыто формирование учётной мысли в разных странах мира. Представлена обобщенная классификация счетов бухгалтерского учёта на основании их исторического развития.

Исследованы предпосылки возникновения двойной записи и порядок её применения. Определен период возникновения термина «бухгалтер» и, как следствие, профессии «бухгалтер». Исследовано составляющие прочесса развития учётной науки за Л. Пачоли. Выделены направления развития учёта в период до 206.

В результате исследования сформированы выводы и предложения.

Ключевые слова: учёт, счета, учётные школы, развитие учёта, счетоводство, двойная запись.

Табл.: 4. Лит.: 13.

Постановка проблеми. Ступінь розвитку науки визначається тим, на скільки вивчена ії історія. Це стосується й такого елементу методу бухгалтерського обліку, як бухгалтерські рахунки. Ще 3 давнини на рахунках велася реєстрація фактів господарського життя. Спочатку виникло рахівництво, так звана практична діяльність, яка була пов'язана безпосередньо з веденням рахункових записів та їх перенесенням у відповідні книги. Лише згодом на основі рахівництва з'являлися наукові розробки і бухгалтерський облік почав формуватися як сукупність теоретичних знань (рахункознавство) [1].

Професія бухгалтера має свої історичні витоки та давно сформувалася як практична діяльність. Проте наукова основа бухгалтерського обліку вимагає подальшого розвитку та розуміння з боку сучасних бухгалтерів.

Ефективна господарська діяльність в умовах ринкової економіки та глобальних інтеграційних процесів можлива лише за достатньої поінформованості [12].

Господарські операції знаходили своє відображення на великій кількості бухгалтерських рахунків. Вони відображають інформацію тільки щодо однорідних господарських операцій та залежать від об'єктів обліку, через що на практиці необхідно знати характеристику кожного рахунку (зміст, функції та призначення) та розуміти, яку інформацію обліковувати. Це сприяє: застосуванню єдиних підходів до відображення господарських операцій у практичній діяльності суб'єктів державного сектора; отриманню необхідних показників для контролю й аналізу; прийняттю правильних управлінських рішень [2].

Що стосується використання рахунків обліку для потреб формування соціальної складової, то вона вимагає деталізації за операціями [13]. 
Аналіз останніх досліджень і публікацій. Питанням становлення та розвитку рахункознавства приділено увагу з боку таких вчених, як: К.М. Боримська [1], Е.В. Калюга [2], Л.В. Гуцаленко [12]. Д.О. Клименко [4], М.А. Кипарисов [5], Ф.Ф. Бутинець [6], Н.Л. Правдюк [13], Я.В. Соколов [7], М.Я. Остап'юк [10], Л.В. Івченко [11] та ін. Однак зміна законодавства, гармонізація вітчизняного та зарубіжного досвіду застосування рахунків, перехід на міжнародні стандарти ведення обліку та звітності спонукає до подальших досліджень.

Формулювання цілей статті. Метою статті $\epsilon$ дослідження історичної періодизації розвитку рахункознавства в розрізі минулого та сьогодення.

Виклад основного матеріалу дослідження. Рахунки бухгалтерського обліку нерозривно пов'язані з самим обліком. У зв'язку з цим, історія виникнення та розвитку рахункознавства тісно переплітається з історичними аспектами формування бухгалтерського обліку як науки.

Починаючи з епохи розвиненого капіталізму (XIX ст.), бухгалтерський облік перетворюється на науку з мистецтва ведення книг, пов'язану з обгрунтуванням формування системи рахунків [1].

У літературі виділяють 4 основні періоди розвитку бухгалтерського обліку (табл.1).

Таблиия 1

Періодизація розвитку бухгалтерського обліку

\begin{tabular}{|c|l|l|}
\hline Етап (період) & \multicolumn{3}{|c|}{ Період } \\
\hline I & $\begin{array}{l}\text { 3 моменту виникнення товарно-грошових відносин до кінця 18-ого } \\
\text { століття }\end{array}$ \\
\hline II & 3 кінця 18-го ст. до кінця 19-го ст. & \\
\hline III & кінець 19-го і початок 20-го ст. & \\
\hline IV & 3 початку 20-го і до наших днів & \\
\hline
\end{tabular}

Джерело: сформована автором на основі джерела [11]

На першому етапі виникають способи реєстрації фактів господарської діяльності в облікових регістрах, таких, як: журнали, відомості та ін., що мають вигляд хронологічних та систематичних записів. На даному етапі починає широко застосовуватися подвійний запис.

Революційні перетворення у виробничій галузі, розвиток фізичних форм товарних відносин й зростання обсягів різноманітних операцій (фінансових, торгівельних та ін.) не лише в окремих країнах, але й в цілому світі - все це супроводжує другий період розвитку бухгалтерського обліку. Зазначений період характеризується виданням значної кількості праць 3 питань бухгалтерського обліку, виникають різноманітні теорії: юридична - у Франції, матеріалістична (економічна) - в Італії, камеральна - в Німеччині тощо. Історичне значення даного періоду полягає в наступному: окреслено основні вагомі напрямки становлення науки «рахівництво», відповідно до яких відбувся і ії подальший розвиток [4].

Третій період характеризується становленням обліку господарських операцій як однієї з галузей наукових знань. Протягом цього етапу встановлювалися теоретичні аспекти бухгалтерського обліку, окреслювалася площина тих явищ та процесів, вивчення яких є об'єктом даної науки. При цьому праці авторів були спрямовані на формулювання цілей бухгалтерського обліку та формування понятійного апарату. 
Четвертий період включає кілька стадій [4].

На першій стадії, що охоплює період до середини 20-го ст., відбувається розробка базових принципів об'єктивної оцінки майново-правового стану самостійного суб'єкта господарювання, спостерігається галузевий напрямок у побудові облікової системи, розширення державної регламентації національних систем бухгалтерського обліку та звітності.

Друга стадія, що розпочалась із середини 20-го ст. і триває до наших днів, характеризується розробкою основних принципів оцінки правового та майнового станів господарюючих суб'єктів в умовах зовнішнього ринкового середовища та у зв’язку з прийняттям належних управлінських рішень для забезпечення отримання економічної вигоди в майбутньої.

Пам’ятки історії свідчать про наявність в різних країнах Стародавнього світу обліку господарських операцій та різноплановість його характеру. Так за тих часів існують свідчення виникнення та застосування подвійного запису, що відображав надходження та вибуття продуктів та інших матеріальних цінностей.

У Стародавньому світі облік базувався виключно на фактах, тобто займав статичну позицію. Основою статичного обліку є пряма реєстрація майна та регулярне проведення інвентаризації. Пряма реєстрація передбачала зазначення певного об'єкта.

Згодом з'явилася непряма реєстрація, що передбачала використання даних 3 «первинних документів» для фіксації об'єкта. Таким чином, облікові працівники почали використовувати підтверджувальні документи, які лягли в основу теперішніх первинних.

Передумовою суворої регламентації обліку став елліністичний період. Це етап в історії розвитку Східного Середземномор'я в кінці 4-1 ст. до н. е., що характеризувався модернізацією економічних відносин та особливою увагою та педантичністю щодо обліку здійснюваних операцій.

У Стародавньому Римі поступово завершився розвиток початкового бухгалтерського обліку. Облікова система Риму значною мірою запозичила практично усі позитивні сторони та переваги грецької і східної облікової думки, враховуючи власні умови господарювання та інтереси власників. Виникли такі облікові регістри, як: прибутково-видаткова книга та книга рахунків клієнта. Зазначені регістри заповнювала банківська бухгалтерія. Прибутково-видаткова книга була універсальним документом. Вона використовувалася скрізь: і в домашньому господарстві, і в торгівлі. Виникнення книг, визначень та термінів, які застосовуються в теперішньому обліку (конкуренція, дебітор, депозит, акцепт, сума, кредитор тощо) - це те, що отримала сучасна бухгалтерія завдяки цій країні [11].

В Греції вперше з'явились такі поняття, як матеріальна відповідальність та інвентаризація. Виникли перші принципи класифікації рахунків: матеріальні, особові та фінансові [4].

Розуміння економічного змісту рахунку та правильності його застосування лежить в основі ведення бухгалтерського обліку. Тому дуже важливим є питання класифікації рахунків за різними ознаками.

«Формування рахунків відповідно до викладених правил визначає класифікацію рахунків. Класифікація рахунків - це науково обгрунтоване групування рахунків, тобто розподіл рахунків на групи та підгрупи за будь-якими однорідними суттєвими ознаками» [6,7]. 
Класифікація рахунків повинна: з'ясувати зміст, функції та призначення рахунку, його принципову відмінність або спільне з іншими рахунками; вміти використовувати будь-який рахунок у практичній діяльності; застосовувати необхідні орієнтири при побудові Плану рахунків [8].

На сьогодні існує велика кількість класифікацій рахунків, однак слід пам'ятати, що «всі господарські процеси, активи і капітал повинні відображатися на рахунках; враховуватися особливості функціонування суб' єктів державного сектора; відображатися юридична структура капіталу; передбачатися розміщення облікових об'єктів за матеріальними категоріями, господарськими процесами і ліквідністю активів; пристосовуватися до подальшої деталізації рахунків» [9].

Класифікація зводиться не просто до впорядкування фіксованого набору бухгалтерських рахунків, а полягає у формуванні системи рахунків, що базується на дослідженні процесів, які складають діяльність суб'єктів господарювання, аналізі інформаційних потреб для їх відображення і виявлення можливого отримання цієї інформації [2].

Узагальнена класифікація рахунків наведена в таблиці 2.

Таблиия 2

Загальна класифікація рахунків бухгалтерського обліку [9]

\begin{tabular}{|c|c|c|}
\hline $\begin{array}{l}\text { № } 3 \mathbf{a} \\
\text { II/II }\end{array}$ & $\begin{array}{c}\text { Відповідно до } \\
\text { класифікаційних ознак }\end{array}$ & Значення \\
\hline 1 & 2 & 3 \\
\hline \multicolumn{3}{|c|}{ Щодо підсумку балансу } \\
\hline 1. & Балансові рахунки & прямо відображаються в балансі у відповідних статтях \\
\hline 2. & Позабалансові рахунки & не відображається (фіксується поза балансом) \\
\hline \multicolumn{3}{|c|}{ Щодо сальдо рахунків } \\
\hline 3 , & $\begin{array}{l}\text { Безпосередньо відображаються } \\
\text { в Балансі }\end{array}$ & сальдо яких безпосередньо відображається в балансі \\
\hline 4, & $\begin{array}{l}\text { Не відображаються прямо в } \\
\text { балансі }\end{array}$ & сальдо переноситься на інший рахунок \\
\hline \multicolumn{3}{|r|}{ За видом сальдо } \\
\hline 5. & Дебетові & рахунки, які мають дебетові сальдо \\
\hline 6. & Кредитові & рахунки, які мають кредитове сальдо \\
\hline \multicolumn{3}{|c|}{ За значенням сальдо } \\
\hline 7. & Чисті & $\begin{array}{l}\text { господарська маса сформована за однією, чітко } \\
\text { окресленою групувальною ознакою }\end{array}$ \\
\hline 8. & Мішані & $\begin{array}{l}\text { господарська маса сформована за декількома нечітко } \\
\text { окресленими групувальними ознаками }\end{array}$ \\
\hline \multicolumn{3}{|c|}{ За обсягом інформації } \\
\hline 9. & Синтетичні & загальне групування ознак \\
\hline 10. & Аналітичні & детальне групування ознак \\
\hline \multicolumn{3}{|r|}{ За призначенням } \\
\hline 11. & Реальні & за якими стоять конкретні особи та конкретні цінності \\
\hline 12. & Номінальні & $\begin{array}{l}\text { штучно введені в систему рахунків, щоб уточнити } \\
\text { оцінку реальних рахунків }\end{array}$ \\
\hline \multicolumn{3}{|c|}{ За характером розрахунку сальдо } \\
\hline 13. & Які вводяться & $\begin{array}{l}\text { сальдо розраховується безпосередньо із записів за } \\
\text { рахунками }\end{array}$ \\
\hline
\end{tabular}


Продовження табл. 2

\begin{tabular}{|c|c|c|}
\hline 1 & 2 & 3 \\
\hline 14. & Які виводяться & $\begin{array}{l}\text { сальдо визначається шляхом інвентаризаційного } \\
\text { опису, тобто на підставі натуральних показників }\end{array}$ \\
\hline \multicolumn{3}{|c|}{ За юридичним змістом } \\
\hline 15. & Рахунки власника & $\begin{array}{l}\text { поділяються на рахунки власних джерел, які } \\
\text { знаходяться в оперативному управлінні, і рахунки } \\
\text { засобів, які знаходяться у матеріально відповідальних } \\
\text { осіб }\end{array}$ \\
\hline 16. & Рахунки третіх осіб & $\begin{array}{l}\text { поділяються на рахунки юридичних (за видами } \\
\text { відповідальності) і фізичних осіб }\end{array}$ \\
\hline \multicolumn{3}{|c|}{ За економічним змістом } \\
\hline 17. & Інвентарні рахунки & за видами майна або його агентами-зберігачами. \\
\hline 18. & Особисті рахунки & $\begin{array}{l}\text { для відображення розрахунків із будь-якими } \\
\text { юридичними i фізичними особами: дебіторами та } \\
\text { кредиторами }\end{array}$ \\
\hline 19. & Калькуляційні рахунки & $\begin{array}{l}\text { шляхом послідовного накопичення витрат } \\
\text { створюється не одна цінність, а декілька однорідних } \\
\text { або різнорідних цінностей }\end{array}$ \\
\hline 20. & Розподільні рахунки & $\begin{array}{l}\text { враховуються тимчасово суми, що підлягають } \\
\text { розподілу між іншими рахунками; після розподілу } \\
\text { рахунок має бути закритий, сальдо його показує суми, } \\
\text { які ще не розподілені }\end{array}$ \\
\hline 21. & Операційні рахунки & $\begin{array}{l}\text { відкриваються для виявлення результатів будь-якої } \\
\text { однісї, виразно відмежованої від інших, операції або } \\
\text { групи таких операцій }\end{array}$ \\
\hline 22. & Ліквідаційні рахунки & $\begin{array}{l}\text { відкриваються для обліку та } \\
\text { передбачуваних і фактичних витрат, або прибуннків } \\
\text { запланованих і дійсно отриманих }\end{array}$ \\
\hline
\end{tabular}

Таким чином, від об'єктивної класифікації синтетичних рахунків залежить не тільки достовірність відображення в обліку зв'язків між об'єктами, які змінюються в результаті господарських фактів, але й організація аналітичного обліку [2].

Точно не відомо винахідника облікової науки. Витоки подвійного запису прослідковуються з 13-14 ст. у деяких торгівельних частинах Північної Італії. При цьому історичні передумови виникнення системи подвійного запису в містах Італії були окреслені в працях відомого американського науковця А.Ч. Літтлтона.

А.Ч. Літтлтон вважає, що кожна із зазначених ним передумов існувала окремо в різних місцях і в різний час, однак одночасно вони жодного разу не проявлялись. Поєднання даних передумов спостерігалось, коли Хрестові походи забезпечили масове переміщення людей через країни Північної Італії (тоді ще не єдиної), яка слугувала центром торгівлі між Свропою та Близьким Сходом [4].

Епоха відродження характеризується виникненням терміну «бухгалтер» (звідси і - бухгалтерія) і виникненням такої посади, як «бухгалтер». У 1499 р., імператор Максиміліан постановив, щоб у казначействі був старанний працівник, який би акуратно та старанно заповнював облікові книги і називався бухгалтером. Першим бухгалтером був названий Христофор Штехер [5, С. 94]. Він був діловодом Інсбрукської облікової палати. 


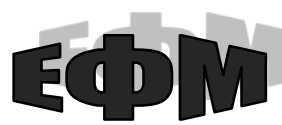

http://efm.vsau.org/

Епоха Середньовіччя характеризується розвитком облікової справи в таких країнах, як: Голландія, Франція, Англія, Іспанія, Ватикан, Італія та в інших країнах Західної Свропи. Протягом епохи Ренесансу здійснено значний крок в розвитку обліку, зокрема у його систематизації.

Широкого використання набула подвійна бухгалтерія, що отримала основне визнання в Європі. Іоганн Вольфганг Гете через свого героя зазначає, що подвійна бухгалтерія є наймогутнішим відкриттям людського інтелекту. В Німеччині до 1498 p. працювали писці - особи, які займалися веденням облікових книг. 3 цього періоду терміни «бухгалтер» та «бухгалтерія» почали витісняти старі назви [10].

У 15 ст. в окремих купецьких підприємствах бухгалтерський облік, як сформована система, набула літературного оформлення. Першою літературною обліковою працею стала праця Венедикта Кортуллі «Про торгівлю і досконалого купця» у 1458 р., однак надрукована вона була лише у 1573 р. Робота була присвячена торгівлі, а саме, організації та техніці ії ведення. Бухгалтерський облік у ній розглядався як один із важливих інструментів управління окремим підприємством. У зв'язку з цим, автор присвятив йому окрему частину. Що ж стосується конкретної дати виникнення подвійної бухгалтерії, то науковці не можуть ії точно назвати. Таку ж думку має і відомий дослідник Раймонд де Рувер. У своїй праці «Як виникла подвійна бухгалтерія», перекладеній російською мовою та виданій у Росії у 1958 р., він вказує на те, що подвійна бухгалтерія зародилась в Італії приблизно між 1250 та 1350 pp. [4].

За історичними даними вперше систематизацію обліку здійснив францисканський монах, математик зі світовим ім'ям, учень П'єра делла Франческа і Леона Батіста Альберті, людина універсальних знань, друг і вчитель Леонардо да Вінчі - Лука Пачолі. Його слава грунтується на відомому трактаті про рахунки і записи, який увійшов до складу фундаментальної праці «Сума арифметики, геометрії, вчення про пропорції і відношення» [5, с.74].

Ця праця була перекладена багатьма мовами і є основною в розвитку облікової теорії та практики, а за ступенем впливу на розвиток обліку з нею не може зрівнятися жодна інша праця.

Історичні дослідники виокремлюють п’ять складових, які Лука Пачолі вніс до процесу розвитку бухгалтерського обліку (табл. 3).

Таблиияя 3

Складові процесу розвитку облікової науки

\begin{tabular}{|c|l|}
\hline $\begin{array}{c}\text { № } \\
\text { п/п }\end{array}$ & \multicolumn{1}{|c|}{ Складові } \\
\hline 1 & \multicolumn{1}{|c|}{2} \\
\hline 1 & $\begin{array}{l}\text { Теоретичне обгрунтування подвійного запису. Л. Пачолі був першим, хто спробував } \\
\text { пояснити поняття дебет і кредит, хоча сам їх не вживав. Він створив персоналістичну } \\
\text { модель обліку і тим самим заклав основи його юридичного тлумачення, яке пізніше } \\
\text { знайшло своє відображення у відомих працях Е. Дегранжа і Дж. Чербоні. Видатний } \\
\text { французький бухгалтер П. Гарньє назве свою книгу «Облік - алгебра права», в якій } \\
\text { принцип подвійного запису пояснить, виходячи з причинно-наслідкових зв'язків } \\
\text { (кредит - причина, дебет - наслідок). Персоналістична модель виявилась настільки } \\
\text { вдалою, що нею зацікавились і використовували у своїх геніальних працях К. Маркс і } \\
\text { Ф. Енгельс при поясненні подвійного запису }\end{array}$ \\
\hline 2 & $\begin{array}{l}\text { Персоналістична модель унеможливила самостійний розгляд таких абстрактних } \\
\text { бухгалтерських категорій, як дебет і кредит, що призвело до створення умов для } \\
\text { виділення бухгалтерського обліку в окрему науку }\end{array}$ \\
\hline
\end{tabular}


Продовження табл. 3

\begin{tabular}{|c|l|}
\hline 1 & \multicolumn{1}{|c|}{2} \\
\hline 3 & $\begin{array}{l}\text { Лука Пачолі розглядав бухгалтерський облік як самостійний метод, що базується на } \\
\text { застосуванні подвійного запису і використовуєтья для відображення господарських } \\
\text { процесів, які відбуваються на окремому підприємстві та за його межами. Таке } \\
\text { тлумачення відрізнялося від думки В. Котрулі, який вважав, що об’єктом } \\
\text { бухгалтерського обліку є окреме підприємство }\end{array}$ \\
\hline 4 & $\begin{array}{l}\text { Подвійний запис на рахунках трактуєтьяя як система обліку, що не може бути } \\
\text { постійною і залежить від мети, яку переслідуєадміністрація }\end{array}$ \\
\hline 5 & $\begin{array}{l}\text { Л. Пачолі вперше ввів у бухгалтерський облік моделювання, що базувалося на } \\
\text { комбінаториці. Це дало можливість побудувати загальну модель, в межах якої будь- } \\
\text { який обліковий факт пояснюється, як окремий випадок }\end{array}$ \\
\hline
\end{tabular}

Джерело: сформована автором на основі джерела [4]

Учений був першим, хто зібрав і систематизував усю інформацію про прийоми, що використовувалися купцями того часу під час здійснення своїх торгових рахунків і записів. Тим самим Л. Пачолі заклав фундаментальні основи розвитку обліку як науки, виводячи його з суто практичної діяльності. Порядок використання подвійного запису, що бере свій початок у середньовічній Італії, привернув до себе увагу багатьох відомих вчених того часу. Бухгалтерський облік став предметом наукових розробок та досліджень. У той період в історії розвитку обліку було закладено фундамент для зародження та становлення науки - бухгалтерії. Незважаючи на всі негативні фактори і те, що розвиток обліку відбувався в епоху пізнього Середньовіччя, саме завдяки їм виникла така посада, як бухгалтер і термін «бухгалтерія» [11].

Кінець п’ятнадцятого століття характеризується занепадом італійських міст.

Період відкриття Нового Світу та пошуку нових оптимальних торгових шляхів характеризується зміщенням центру торгівлі в такі країни, як Іспанія і Португалія, а потім - Антверпен і Нідерланди. Досить природно, що італійська система подвійної бухгалтерії розповсюджувалась і на інші країни. Визначний Історик Раймонд де Рувер охарактеризував період розвитку обліку з 1494 по 1800 рр. як епоху Застою, що не зовсім відповідає дійсності, тому що саме в цей період закінчились усі революційні перетворення й почались серйозні наукові дослідження. Зміни світу призводили до зміни системи обліку [4].

До кінця 19 ст. система бухгалтерського обліку, основи якої були закладені Лукою Пачолі, зазнала певних змін, що були пов'язані із специфікою господарської діяльності великих промислових корпорацій:

1) створені перші компанії, які були відокремленні від їх власників;

2) виник акціонерний капітал;

3) розмежовано капітал і прибуток;

4) введено поняття «діюче підприємство»;

5) почали працювати фондові біржі;

6) розширилась промисловість і торгівля;

7) на сцені з'явилися люди облікової професії [6, с. 26].

Саме життя висувало нові вимоги до бухгалтерії. Постійні різноманітні відкриття та винаходи створювали нові форми промисловості й торгівлі; розросталася мережа залізниць; постійно оновлювалась та розвивалась галузь пароплавства; розростались торгові центри; розвивались пошта і телеграф; набули широкого використання векселі 


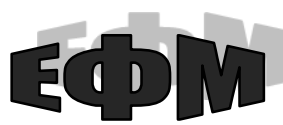

http://efm.vsau.org/

та чеки; відбулися перетворення у кредитній системі та системі обміну; зростав обсяг операцій на біржі та торговий оборот більшості корпоративних підприємств; зростав освітній рівень населення. Усе це сприяло усвідомленню необхідності раціональної, ефективної звітності, яка неможлива без бухгалтерії [4].

Середина дев'ятнадцятого століття - це той рубіж, який характеризувався стрімким розвитком облікової думки науковців в різних країнах світу. В цей період у науковій літературі виникають твердження щодо необхідності відтворення та розвитку бухгалтерії, іiі застосування на підприємствах торгівлі та промисловості. Такі ідеї були провідними в Німеччині та Австрії, де формувались комерційні школи зі змістовним та ретельним викладанням бухгалтерії. У загальноосвітніх училищах теж викладався курс бухгалтерії, проводились публічні лекції та читання з питань рахівництва в прикажчицьких товариствах та ферейнах, організовувалися диспути на конференціях бухгалтерів [11].

Згодом почали видаватися нові змістовні праці з бухгалтерії, все частіше на підтримку обліку почали виступати наукові діячі, посилилася робота, і бухгалтерія почала перетворюватись з мистецтва на науку, що набувала все більшого значення в житті та економіці. Поступово науковці дійшли висновку, що рахівництво теж $\epsilon$ наукою. Воно визначає предмет й досліджує та розкриває його так, як не вивчає та не розкриває жодна інша наука. Рахівництво має свою загальну теорію знання, свій певний особливий метод дослідження i, як утилітарна наука, своє прикладне знання, як практичний додаток до загальної теорії та методу [4].

У цей період, з 1870 року і до початку 20 ст., наукова робота в галузі рахівництва стала ще більш інтенсивною, з'явилось багато змістовних праць, що стосувались його теорії та практики [10, с. 79]. Усі праці тогочасних вчених були націлені на розвиток теорії рахівництва за напрямками, що були окреслені їх попередниками, а саме: економічний та юридичний. Тому можна твердити про однакову паралельну спрямованість розвитку рахівництва та облікової науки.

Поряд $з$ подвійною бухгалтерією з'являється вчення про інші системи, в тому числі і про потрійну бухгалтерію. Такий стан справ посилив увагу науковців до розвитку облікової справи як науки.

Французькі вчені висунули доктрину трьох функцій обліку: 1) рахівничої, пов'язаної з розробкою спеціальної логіки, класифікацією об'єктів рахунків тощо; 2) соціальної, що порівнює інтереси різних суб'єктів суспільних відносин; 3) економічної, що дозволяє за допомогою облікової інформації здійснити управління господарськими процесами [6].

Значний внесок у розвиток облікової теорії зробила американська школа рахівництва. Через обмежений характер участі держави в регулюванні економіки (у порівнянні 3 Свропою) і специфіку англо-американської системи права ідеї американської облікової школи значно відрізняються від європейської концепції [11].

Традиційно бухгалтерський облік у США був націлений, в першу чергу, на задоволення інтересів керівників та власників і застосовувався, в основному, як інформаційна база для прийняття рішень з управління виробництвом. Завдяки цьому спеціалісти США спрямовували основну увагу на розробку різноманітних економічних методик щодо оцінки та узагальнення фактів діяльності підприємств, організацій та установ, а також їх застосування в залежності від умов функціонування підприємства і цілей власника [4]. 
Вперше систему управлінського обліку було застосовано на фабриці Ліман Міллс у 1855 році 3 метою підвищення ефективності моніторингу процесу виробництва. Поряд з цим велику увагу було приділено оцінці запасів. Так було розроблено методи оцінки запасів за цінами: ФІФО - перших за надходженням партій, ЛІФО - останніх за надходженням партій та НІФО - за цінами відшкодування. Окремими з них ми користуємося і сьогодні.

У першій половині дев'ятнадцятого століття формується бухгалтерська школа в Росії. Її засновником виступає Карл Арнольд, німець за походженням, який запровадив багато нововведень до облікової системи: перш за все, це відкриття рахунків через рахунок капіталу, введення синтетичного обліку товарів та інших активів тощо. Ця школа розвивалась в напрямку ідей та методів німецької школи через те, що в Росії велика кількість бухгалтерів була вихідцями з Німеччини. Проте існували намагання використати й інші доктрини. Ф. Єгерський, відомий учений, батько потрійної бухгалтерії, спробував дати фінансове трактування обліку, яке виявилось досить близьким до ідей французької школи [7].

Напрямки розвитку вітчизняної бухгалтерської науки до початку 20 ст. наведемо в таблиці 4.

Таблиия 4

Напрямки розвитку обліку за обліковою літературою у період до 20 ст.

\begin{tabular}{|c|l|}
\hline $\begin{array}{c}\text { № } \\
\text { п/п }\end{array}$ & \multicolumn{1}{|c|}{ Напрям розвитку } \\
\hline 1 & $\begin{array}{l}\text { Висвітлення в літературі рекомендацій з дотримання правил ведення бухгалтерського } \\
\text { обліку на підставі вже існуючих шкіл }\end{array}$ \\
\hline 2 & $\begin{array}{l}\text { Науковий пошук та виникнення. Початок наукової розробки з питань обліку і } \\
\text { контролю реформаторських течій }\end{array}$ \\
\hline 3 & Початок наукової розробки з питань обліку і контролю \\
\hline
\end{tabular}

Таблиияя сформована автором на основі джерела [4]

Тож можна говорити про певну схожість Української національної моделі обліку та Німецької школи, яка зробила свій вагомий внесок у розвиток світової бухгалтерії. В цілому ж, підсумовуючи, слід зауважити, що на шляху, який пройшов облік від часів свого зародження в давнину до часу, коли він перетворився у науку, мав певну циклічність та підпорядкованість загальним законам філософії та історичного суспільного розвитку, що має вагоме значення для майбутніх наукових досліджень в сфері бухгалтерського обліку [4].

Висновки. Отже, історичний екскурс у розвиток обліку та рахівництва дає можливість стверджувати, що облік тісно взаємопов'язаний з іншими науками.

Слід також зазначити, що рахівництво, як практична діяльність, та рахункознавство, як наука, взаємопов'язані між собою.

До вивчення обліку як науки необхідно підходити комплексно, що означає використання отриманих знань при вивченні інших суміжних з обліком наук при побудові та дослідженні різних нових облікових моделей.

Застосування вищезазначеного дасть змогу суттєво вдосконалити чинну облікову практику на діючих підприємствах та підвищити ефективність їх функціонування. 


\section{Список використаних джерел}

1. Боримська К.П. Розвиток рахункознавства: історія та перспективи / К.П. Боримська // Вісник ЖДТУ. 2006. №4 (38). С. 7-19.

2. Калюга Е.В. Підходи до класифікації рахунків бухгалтерського обліку: історичний аспект / Е.В. Калюга // Економічні науки. Серія «Облік і фінанси». 2014. Випуск 11 (41). Ч. 2. С. 131-143.

3. Боримська К.П. План рахнків бухгалтерського обліку як інтегрована облікова модель: підходи до побудови / К.П. Боримська // Вісник ЖДТУ. 2010. №3 (53). С. 37-43.

4. Клименко Д.О. Зародження бухгалтерії та формування бухгалтерського обліку як науки / Д.О. Клименко // «Економічні науки». Серія «Облік і фінанси». 2011. Випуск 8 (29). Ч. 1. С. 236-245.

5. Кипарисов М. А., Курс Теории бухгалтерського учёта. М., Гос План Издат. 1940. С. 284.

6. Бутинець Ф.Ф. Теорія бухгалтерського обліку: Підручник для студентів вузів спеціальності 7.050106 «Облік і аудит»/Вид.2-е, доп. і перероб. Житомир. ЖІТІ, 2000. 640c.

7. Соколов Я.В. Основы теории бухгалтерского учёта. М.: «Финансы и статистика», 2000, 456 с.

8. Теория бухгалтерского учёта: Учеб. пособие для вузов /Под ред. проф. Н.П. Любушина. 2-е изд., перераб. и доп. М.: ЮНИТИ-ДАНА, 2003. 312с.

9. Соколов Я.В. Бухгалтерский учёт как сумма фактов хозяйственной жизни. М.: Магистр, 2010.

10. Остап'юк М.Я., Лучко М.Р., Даньків Й.Я. Історія бухгалтерського обліку: Навч. посіб. К.: Знання, 2005. 276 с.

11. Івченко Л.В. Історичні аспекти розвитку бухгалтерського обліку / Л.В. Івченко // Фінанси, облік і аудит. 2011. № 18. С. 284-291.

12. Гуцаленко Л.В. Обліково-інформаційна система забезпечення управління сільськогосподарським підприємством / Л.В. Гуцаленко, Е.О. Довгаль // ЕКОНОМІКА. ФІНАНСИ. МЕНЕДЖМЕНТ: актуальні питання науки і практики. 2016. №8. C. 82-92.

13. Правдюк Н.Л. Соціальні аспекти бухгалтерського обліку / Н.Л. Правдюк // ЕКОНОМІКА. ФІНАНСИ. МЕНЕДЖМЕНТ: актуальні питання науки і практики. 2017. №12. C. 91-102.

\section{References}

1. Borymska K.P. (2006). Rozvytok rakhunkoznavstva: istoriia ta perspektyvy [Development of accountancy: history and perspectives].Visnyk ZhDTU - Bulletin of ZhDTU, №4 (38), 7-19 [in Ukrainian].

2. Kaliuha E.V. (2014). Pidkhody do klasyfikatsii rakhunkiv bukhhalterskoho obliku: istorychnyi aspekt [Approaches to the classification of accounting accounts: historical aspect]. Ekonomichni nauky. Seriia «Oblik i finansy»-Economic sciences. Series "Accounting and Finance", Issue 11 (41), part 2, pp. 131-143[in Ukrainian].

3. Borymska K.P. (2010). Plan rakhnkiv bukhhalterskoho obliku yak intehrovana oblikova model: pidkhody do pobudovy [Accounting Accounting Plan as an Integrated Accounting Model: Approaches to Construction]. Visnyk ZhDTU - Bulletin of ZhDTU, №3 (53), 37-43 [in Ukrainian]. 


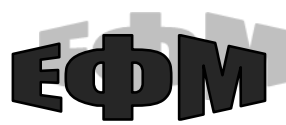

http://efm.vsau.org/

4. Klymenko D.O. (2011). Zarodzhennia bukhhalterii ta formuvannia bukhhalterskoho obliku yak nauky [The origin of accounting and accounting as a science]. Ekonomichni nauky. Seriia "Oblik i finansy» - "Economic sciences". Series "Accounting and Finance", Issue 8 (29), part 1, pp. 236-245 [in Ukrainian].

5. Kiparisov M.A. (1940). Kurs Teorii bukhgalterskogo Uchiota [Course of Accounting Theory]. Moskow, Gos Plan Izdat, p. 284 [in Russian].

6. Butynets F.F. (2000). Teoriia bukhhalterskoho obliku: Pidruchnyk dlia studentiv vuziv spetsialnosti 7.050106 "Oblik i audyt" [Theory of Accounting: A textbook for university students specialty 7.050106 "Accounting and Audit"]. Zhytomyr, ZhITI, 640 [in Ukrainian].

7. Sokolov Ya.V. (2000). Osnovy teorii bukhgalterskogo uchiota [Basics of accounting theory]. Moskow: «Finansy i statistika», 456 [in Russian].

8. Liubushyn N.P. (2003). Teoriya bukhgalterskogo uchiota: Ucheb. posobiye dlia vuzov, 2-e izd., pererab. i dop [Theory of accounting: manual for high schools]. Moskow: YuNYTY-DANA, 312 [in Russian].

9. Sokolov Ya.V. (2010). Bukhgalterskiy uchiot kak summa faktov khoziaistvennoi zhyzni [Accounting as the sum of the facts of economic life]. Moskow: Magistr [in Russian].

10. Ostapiuk M.Ia., Luchko M.R., Dankiv Y.Ia. (2005). Istoriia bukhhalterskoho obliku: Navch. Posib [Accounting History: Manual]. Kyiv: Znannia, 276 [in Ukrainian].

11. Ivchenko L.V. (2011). Istorychni aspekty rozvytku bukhhalterskoho obliku [Historical aspects of accounting development]. Finansy, oblik $i$ audyt - Finance, Accounting and Audit, № 18, pp. 284-291 [in Ukrainian].

12. Hutsalenko L.V. (2016). Oblikovo-informatsiina systema zabezpechennia upravlinnia silskohospodarskym pidpryiemstvom [Accounting and Information System for Agricultural Enterprise Management]. EKONOMIKA. FINANSY. MENEDZhMENT: aktualni pytannia nauky i praktyky - ECONOMY. FINANCES. MANAGEMENT: topical issues of science and practice, №8, 82-92 [in Ukrainian].

13. Pravdiuk N.L. (2017). Sotsialni aspekty bukhhalterskoho obliku [Social aspects of accounting]. EKONOMIKA. FINANSY. MENEDZhMENT: aktualni pytannia nauky $i$ praktyky - ECONOMY. FINANCES. MANAGEMENT: topical issues of science and practice, №12, 91-102 [in Ukrainian].

\section{Відомості про автора}

КОВАЛЬ Любов Віталіївна - кандидат економічних наук, доцент кафедри бухгалтерського обліку, Вінницький національний аграрний університет (21008, м. Вінниця, вул. Сонячна, 3, e-mail: kovalstar@meta.ua).

KOVAL Lubov - Candidate of Economic Sciences, Associate Professor of Accounting Department, Vinnytsia National Agrarian University (21008, Vinnytsia, 3 Soniachna Str., e-mail: kovalstar@meta.ua).

КОВАЛЬ Любовь Витальевна - кандидат экономических наук, доцент кафедры бухгалтерского учёта, Винницкий национальный аграрный университет (21008, г. Винница, ул. Солнечная, 3, e-mail: kovalstar@meta.ua). 